\title{
Municipal Solid Waste Quantification, Characterization and Management in Mylavaram
}

\author{
V. Ramakrishna ${ }^{1}$, Ch. N. Subrahmanyam ${ }^{2}$, S. Bhanuchand ${ }^{2}$, B. Someswara Rao ${ }^{2}$ \\ and A.N.V. Arun Kumar ${ }^{2}$ \\ ${ }^{I}$ Professor, Civil Engineering Department, \\ ${ }^{2}$ Undergraduate students Lakireddy Balireddy College of Engineering, Mylavaram, Krishna District, AP, India
}

\begin{abstract}
Proper quantification and characterization are essential for successful solid waste management. Proper segregation, collection, recovery and systematic disposal are very rarely followed in India, particularly in rural areas. Solid waste management in Mylavaram, a Panchayat in Krishna district, AP is considered in the present study and examined the scope for improvement. Presently, there is no proper implementation of solid waste management practises in Mylavaram except for collection of solid wastes and dumping in two sites outside Mylavaram. Systematic studies are conducted in Mylavaram for quantification, determination of composition, study of route analysis and recovery value from solid wastes. Mylavaram is generating 6000 $\mathrm{kg} /$ day of solid waste with per capita waste generation of $0.27 \mathrm{~kg} /$ day, $71 \%$ food wastes with average density of $302 \mathrm{~kg} / \mathrm{m}^{3}$, moisture content of $70 \%$ and estimated methane gas generation of $253 \mathrm{~m}^{3} /$ tonne of waste. Due to high biodegradable content (4260 kg/day), compost and biogas generation options are studied. Optimum distribution of biodegradable solid waste among these two options is studied. A combination of 2.86 tonnes for composting and 1.4 tonnes for landfilling with net recovery of Rs 7552 per day and Rs 1547 per day from recovery of paper and plastic respectively with a total recovery of Rs27.5 lakhs per year is suggested. This revenue is excluding the construction and operation cost incurred for establishment of compost plant and landfill biogas collection system. In case, biogas is not extracted, a total of 4 hectares land is required to dump the above 1.4 tonnes/day and the residual solid waste generated in Mylavaram. The revenue expected will be only Rs 16.61 lakhs which is obtained from composting and recovery of paper and plastic. Existing route analysis is studied and improvements are suggested to reduce the number of trips of collection.
\end{abstract}

Keywords: Characterisation, Solid waste management, Route analysis, Recovery value, Quantification

\section{Introduction}

India, being the world's second highest populated country and one of the fastest urbanizing countries is facing the problem of solid waste management. Solid waste generated in India is 1,27,486 TPD or 46.5 million tonnes per year as per 2012 status [1] and is expected to increase to 300 million tonnes per year by 2047 [2] thus increasing by $545 \%$ in 35 years. The estimated land requirement for disposal of such huge quantum of waste would be $169.6 \mathrm{~km}^{2}$. Out of the total waste generated in the country 89,334 tonnes (70\%) is collected, 15,881 tonnes $(12.50 \%)$ is being treated while 22,271 tonnes $(17.5 \%)$ is not being collected [1].

The efficiency of solid waste management depends on collection, segregation and transportation of solid waste [3]. In most of the cities, house-to-house collection and segregation are not fully practiced. There is a large gap in between waste collection and processing [4]. The average collection efficiency for MSW in Indian cities is about $72.5 \%$ and around $70 \%$ of the cities lack adequate waste transport capacities [5]. The Calorific value may vary from $800 \mathrm{kcal} / \mathrm{kg}$ to $1000 \mathrm{kcal} / \mathrm{kg}$ and density from $330 \mathrm{~kg} / \mathrm{m}^{3}$ to $560 \mathrm{~kg} / \mathrm{m}^{3}$ [6]. The per capita waste generation ranges from $100 \mathrm{gm}$ to $500 \mathrm{gm}$ based on population of locality [7]. However, the range of per capita generation in India is reported [8] as $0.3-0.6 \mathrm{~kg} / \mathrm{cap} / \mathrm{day}$. Composting, vermicomposting, biogas plant, RDF - pelletization are the recovery techniques adopted in the country [9]. In India only 7\% of the total solid waste collected is composted [10]. Out of the 369 compost plants in India, 177 plants are in operation and 192 are being planned for construction. Goa is operating the maximum number of compost plants (34) in India. Most of the municipalities have no sanitary landfill facility and follow dumping for disposal of MSW [1]. Based on the studies compiled by CPCB in 2011, 59 landfills are constructed in the country, 376 landfills are planned and 1305 landfill sites are identified for future use.

Delhi is generating a solid waste of 6000-8000 TPD @ $0.5 \mathrm{~kg} / \mathrm{capita} /$ day with a biodegradable content of $38.6 \%$, inert content of $31.7 \%$ with an overall moisture content of $43 \%$ [11]. Municipal Corporation of Delhi (MCD) has established various composting plants with a capacity of 1525 TPD in a total area of 28.7 hectares by using aerobic windrow composting technique. Currently, only $10-15 \%$ of solid waste collected is being composted in Delhi with a conversion efficiency of $20 \%$ [10]. The compost that is generated is being sold @ Rs 2400-3000 per tonne [10]. The Government of Delhi also gave permission for 3 new plants for conversion of solid waste into electricity with a total capacity of $66 \mathrm{MW}$. Kolkata city generates approximately $5114.76 \mathrm{TPD}$ @ $1.10 \mathrm{~kg} / \mathrm{cap}-\mathrm{d}$ of MSW. The biodegradable fraction of the solid waste is $44.29 \%$, inerts are $26.82 \%$ and 
moisture content of $46 \%$ [12]. Mumbai is generating 7840 TPD @ $0.63 \mathrm{~kg} / \mathrm{capita} / \mathrm{day}$ with a biodegradable fraction of $38-42 \%$. The solid waste generated in Mumbai is dumped in three dump sites covering a total area of 150 hectares while additional dump sites are proposed in an area of 82 hectares at Kanjur Marg and 40 ha at Mulund [13]. A total of 983 municipal and private vehicles engaged making 1396 trips per day to collect the solid waste [14]. The costs for maintenance of dumping ground, waste transportation and hire charges are accounting to Rs. 126 crores per annum and constitute nearly 28 per cent of the total budget allocated for SWM [13]. Nine states (Maharashtra, West Bengal, Tamil Nadu, Uttar Pradesh, Andhra Pradesh, Kerala, Delhi and Gujarat) account for around $71 \%$ of the solid waste generated in the country $(1,27,486$ TPD) as per 2012 status [1]. Maharashtra accounts for $21 \%$ of the 90,901 TPD solid waste generated from these nine states while Gujarat accounts for $8 \%$ of the solid waste generation (Refer Fig.1).

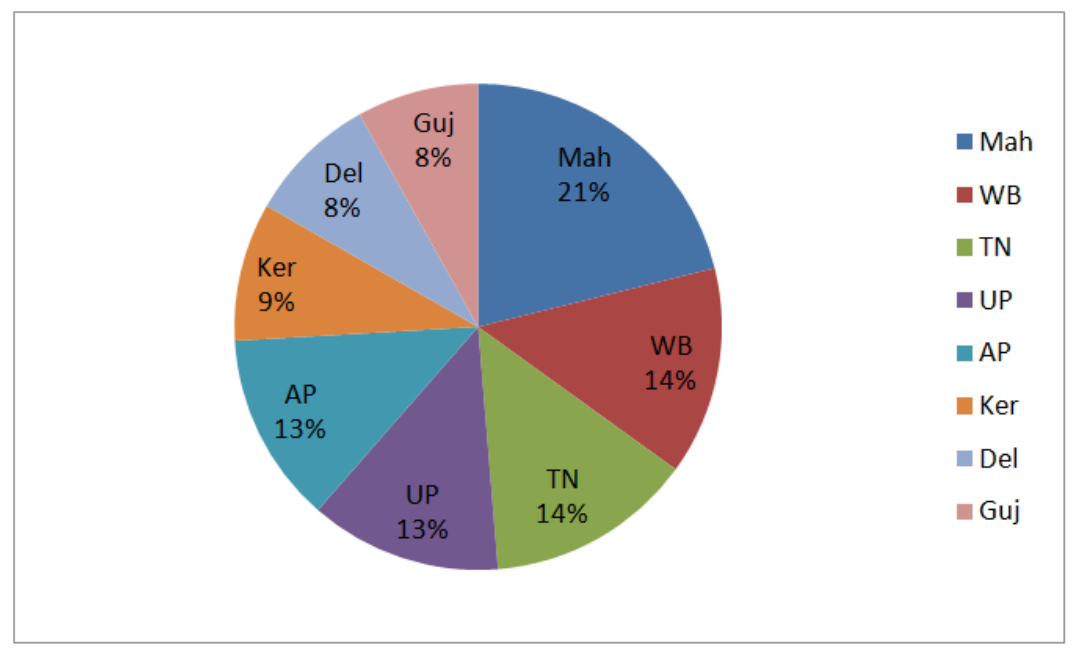

Fig.1 Statistics of SW generation in the country as per 2012 status

Ramakrishna [9] studied the solid waste management from Rajam, a municipality in Srikakulam district, AP with a total population of 42,125 . Rajam is generating $9000 \mathrm{~kg} /$ day of solid waste with per capita waste generation of $0.214 \mathrm{~kg} / \mathrm{day}, 74 \%$ food wastes with average density of $320 \mathrm{~kg} / \mathrm{m}^{3}$ and estimated methane gas generation of $180 \mathrm{~m}^{3} /$ tonne of waste. Optimum distribution of biodegradable solid waste among composting and landfilling options is studied. A combination of 4.66 tonnes of biodegradable solid waste for composting and 2 tonnes for landfilling along with an additional recovery from non biodegradable recoverable materials such as paper and plastic resulting a revenue of Rs.53.73 lakhs per year is suggested.

The Vijayawada urban agglomeration, which is very close $(40 \mathrm{~km})$ to Mylavaram and a major partner in the new capital region of Andhra Pradesh, generates around 604.2 tonnes of solid waste every day out of which Vijayawada Municipal Corporation (VMC) contributes to 573.2 tons and surrounding municipality areas contribute towards 31 tonnes at a per capita generation rate of $0.6 \mathrm{~kg} / \mathrm{cap} / \mathrm{day}$ [15]. The solid waste collection efficiency from VMC and surrounding rural areas recorded $87 \%$ \& $100 \%$ respectively. In addition to the municipal solid waste, 2.76 tonnes of bio-medical waste is also being generated in the city daily, which is handled and disposed of separately. Around $70 \%$ of the city's solid waste generated is organic in nature which is in parts given to two industries for manure (125 tonnes/day) and power generation (225 tonnes/day). The remaining 30\% inorganic waste after extracting the recyclable portion is disposed of ( 150 tonnes/day) through open dumping in railway open dump yard. In addition to these, a bio - methanation plant of 20 tonnes/day using vegetable waste and slaughterhouse waste is being used for methane gas and power generation. A study of solid waste management practices in Mylavaram, a small panchayat in Krishna District and is $40 \mathrm{~km}$ from away from Vijayawada on Vijayawada-Bhadrachalam highway, is considered to study the current practices and the scope for potential improvements in the area. This is a busy area with people from nearby villages commute daily for their business and purchases. Further, a number of educational Institutions including engineering college are located in this area.

\section{Problem Formulation And Methodology}

Mylavaram, a small town which is nearer to AP-CRDA region in Krishna district of Andhra Pradesh with a total population of 21,763 (2011 data) is considered for the study. Mylavaram has been selected based on-

- Increased growth pattern in the past few years

- Increase in establishment of engineering colleges, schools, hostels, commercial establishments

- Nearer to Andhra Pradesh capital region development agency and Vijayawada city. 
- Expansion of road network and improvement of infrastructural facilities and living standards

- Established market place for the surrounding villages.

- Increased solid waste generation due to the above developments

A reconnaissance survey was conducted to study the existing practices and formulate the objectives of the study. It is noticed that,

- At present no systematic procedure is being followed in the collection, recovery and disposal of solid waste generated.

- No proper route analysis is also being followed

- No systematic studies are available for quantification of solid waste

Hence, the present study is taken up with the following objectives:

- To study the existing solid waste management system in Mylavaram

- To study the quantification \& characterization of solid waste

- To estimate the recovery value of solid waste

- To propose better solid waste management practices for Mylavaram

Based on the objectives listed above, the following methodology is drawn in the present study:

- Literature review

- Primary data collection

- Collection of representative solid waste samples

- Segregation of solid waste samples into wet waste (biodegradable) and dry waste (non-biodegradable)

- Laboratory examination for physical properties such as moisture content and density

- Estimation of components in solid waste

- Determination of chemical composition of solid waste

- Quantification of solid waste

- Study of existing collection routes and improvement of the same

- Study of alternatives for waste processing and disposal facilities

- Cost estimation for the options studied

\section{Results And Discussion}

3.1 Study zone: Primary data is collected in Mylavaram [16] to understand the existing practices of solid waste management at Mylavaram and the details are given in Table-1.

Table-1: Details of existing SWM practices at Mylavaram

\begin{tabular}{|l|l|l|}
\hline S No & Item particulars & Details \\
\hline 1 & Total area & $14.57 \mathrm{sq} . \mathrm{Km}$ \\
\hline 2 & Population (2011 data) & 21,763 \\
\hline 3 & Number of residences & 4600 \\
\hline 4 & Collection method & House-to-house \\
\hline 5 & Time of collection & $\begin{array}{l}0600 \mathrm{am}-1100 \mathrm{am} \\
0200 \mathrm{pm}-0500 \mathrm{pm}\end{array}$ \\
\hline 6 & Number of vehicles used for collection of waste & $\begin{array}{l}3 \text { tractors of volume: T1 }\left(2.52 \mathrm{~m}^{3}\right), \mathrm{T} 2\left(3.28 \mathrm{~m}^{3}\right), \mathrm{T} 3(1.70 \\
\left.\mathrm{m}^{3}\right) \& 3 \text { tricycles }\end{array}$ \\
\hline 7 & Dumping yards & $\begin{array}{l}\text { Vijayawada road chinnacheruvu }(2 \mathrm{acres}) \\
\text { Tiruvuru road bye-pass (no data about area) }\end{array}$ \\
\hline 8 & Number of vegetable markets & 2 \\
\hline
\end{tabular}

The following observations are made during the field visit:

- No segregation of solid waste is followed at the time of collection

- Waste carriers are not properly covered leading to spillage during transportation

- Due to improper dumping at the collection points, unhygienic conditions are prevailing that causes various other problems to public during rainy season

- Spreading of solid waste is done by monkeys, dogs, etc. at the primary collection points

- Lack of awareness among people

- No proper timings and systematic route network for collection of solid waste

- Contamination of ground water in the area

- No systematic disposal at final disposal point i.e., irregular firing of solid waste 


\subsection{Collection System:}

In Type-1 system, tri-cycle will collect solid waste from households and dump at road junctions which are treated as a primary collection points. From there tractors will shift to secondary collection points (dump yards) shown in Fig 2(a) and 2(b) below. This procedure is mainly adopted in the areas like Devunicheruvu, Hazipet, S.V.S Nagar etc

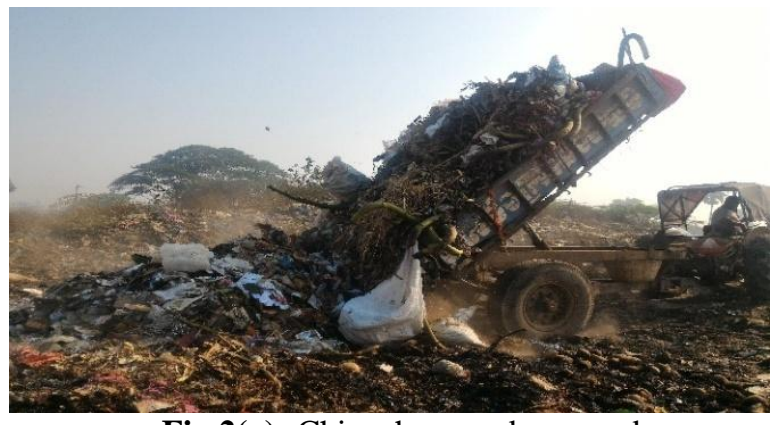

Fig 2(a): Chinacheruvu dumpyard

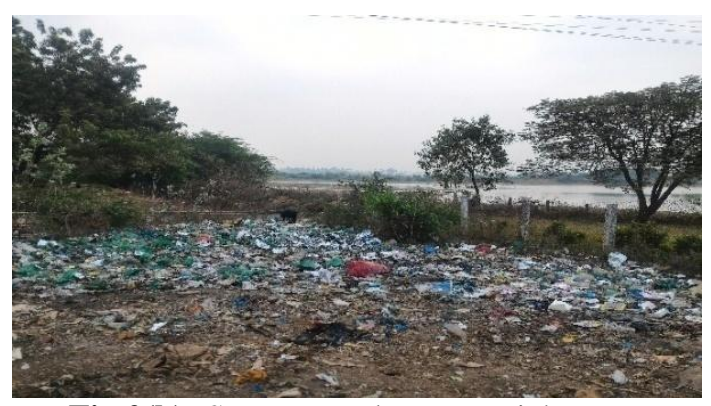

Fig 2(b): Storage yard at Devunicheruvu

In Type-2 system, only tractors will collect solid wastes on main roads, markets, etc. This procedure is adopted in the important areas like MLA guest house, Police station surrounding streets etc. After launching of the Swachah-Bharat scheme, Mylavaram panchayat purchased new tractor. Hence, then onwards, Type-2 method is followed for collecting solid waste for entire Mylavaram.

\subsection{Sampling and laboratory examination}

For the convenience of sampling of solid waste from households, the entire Mylavaram town has been divided into five segments as shown in Fig 3 and segment names are mentioned below:

1. Devunicheruvu.

2. Pondugala road.

3. S.V.S Nagar.

4. Shivalayam area.

5. Nuzvid road.

A, B: Existing dump sites

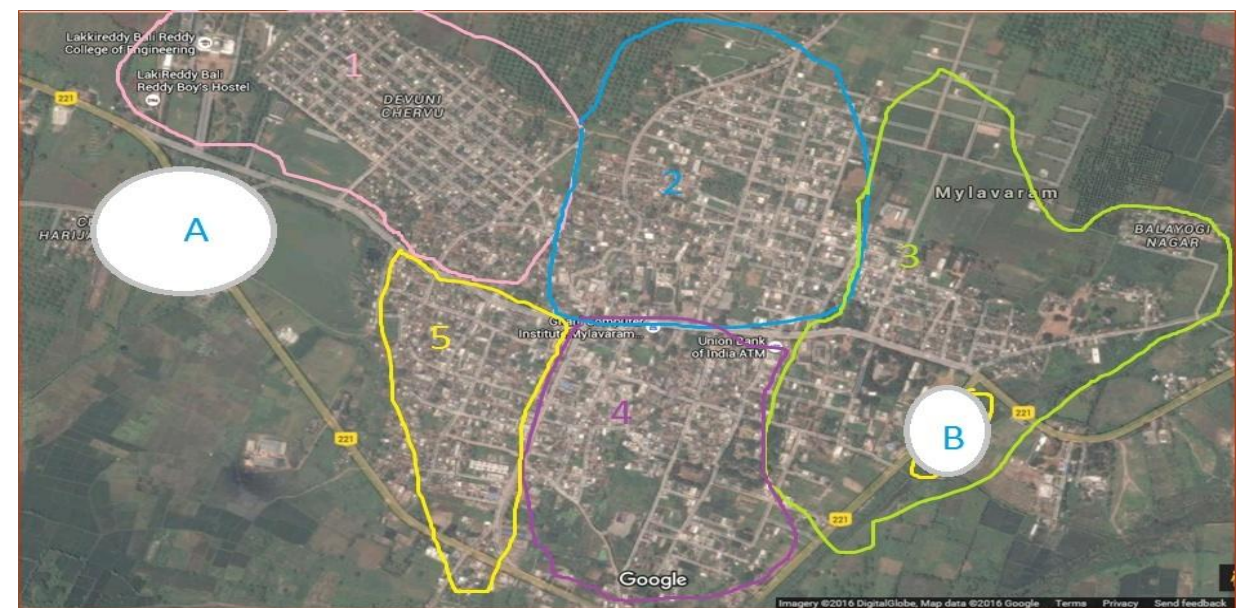

Fig 3: Study zone and the segments considered in the study

Four houses from each of the five segments are randomly selected making a total of $20(=4 \times 5)$ households for daily sampling during the study period. Sampling is carried out for one week to account for daily variations during one entire week. The 20 households are consulted before commencement of sampling and obtained their consent for the study purpose. Two bags are given to each of the houses, one for keeping wet waste and the other for dry waste. Solid waste samples are collected for one week during February-2016. The total samples collected during sampling are: 2 bags $\mathrm{x} 4$ houses $\mathrm{x} 5$ segments $\mathrm{x} 7$ days $=280$ comprising of 140 wet (biodegradable waste) samples, 140 dry (non-biodegradable waste) samples. All the samples are examined 
in the laboratory for the determination of moisture content, density and composition. For quantification purposes, the average number of persons per house is considered as four.

\subsection{Component separation and quantification}

The total weight of the waste collected is noted down as W. Components of the waste such as plastic, cardboard, paper etc. are separated from solid waste (Refer Fig.4). They are collected in a container of empty weight $\mathrm{W} 1$. The weight of container along with individual component is measured as W2. The individual weight of the component $\mathrm{Wc}=\mathrm{W} 2-\mathrm{W} 1$, is thus calculated. The percentage of each component is calculated using the formula [17]: \% of the component $=(\mathrm{Wc} / \mathrm{W}) \times 100$

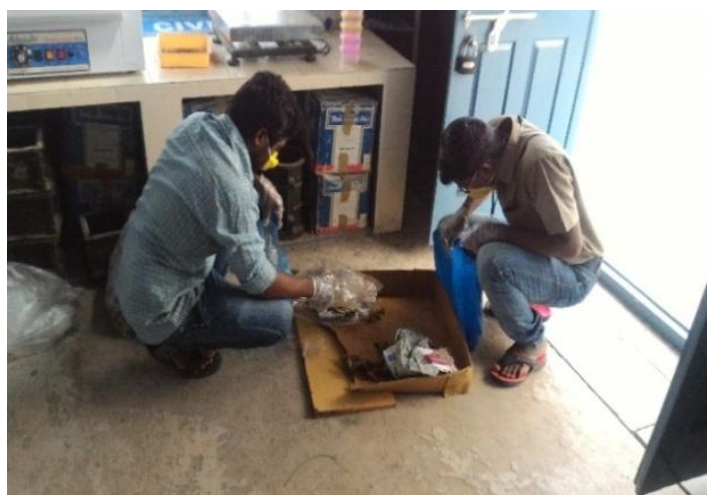

Fig. 4(a) Component separation of solid waste

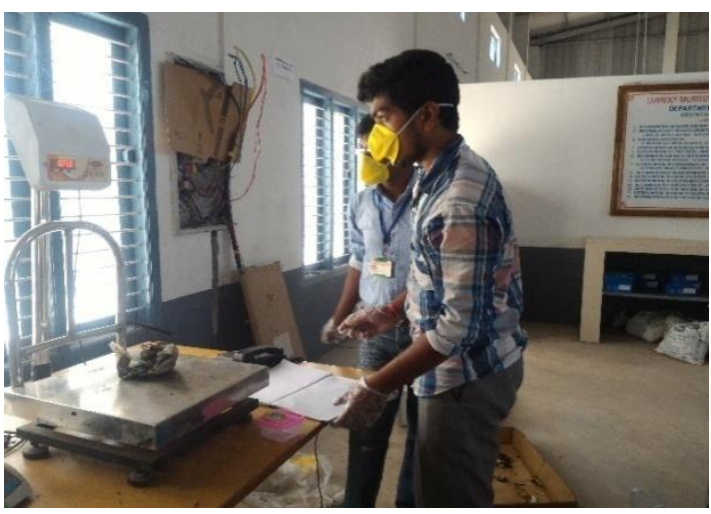

Fig. 4 (b) Quantification of solid waste

The computations for estimation of components from solid waste are shown in Table-2 for one (A1) of the five areas identified for sample collection. For each house, the quantity of wet waste and dry waste are determined. The major components identified in the study area are paper, plastic, iron and miscellaneous items since this is a rural area. The quantity and subsequently percentage are computed for solid waste from each of the four houses ( $\mathrm{H} 1$ to $\mathrm{H} 4)$ where samples are collected. The procedure is repeated for all the five areas A1 to A5 each day. The results are given in Table-3. The average values obtained from the 7 days of sampling are calculated.

Table-2: Computation for calculation of components of solid waste

\begin{tabular}{|c|c|c|c|c|c|c|c|c|}
\hline \multirow{2}{*}{ Area } & \multirow{2}{*}{ House No } & \multirow{2}{*}{$\begin{array}{l}\text { Dry } \\
\text { Wt./\% }\end{array}$} & \multirow{2}{*}{$\begin{array}{l}\text { Wet } \\
\text { Wt./\% }\end{array}$} & \multirow{2}{*}{ Total Wt./\% } & \multicolumn{4}{|c|}{ Dry components/\% } \\
\hline & & & & & Paper & Plastic & Iron & Misc \\
\hline \multirow{8}{*}{ A1 } & \multirow{2}{*}{$\mathrm{H} 1$} & 0.210 & 0.36 & 0.57 & 0.140 & 0.07 & - & - \\
\hline & & 36.58 & 63.15 & 99.99 & 24.56 & 12.22 & - & - \\
\hline & \multirow{2}{*}{$\mathrm{H} 2$} & 0.670 & - & 0.670 & - & 0.170 & - & 0.500 \\
\hline & & 100 & - & 100 & - & 25.37 & - & 74.62 \\
\hline & \multirow{2}{*}{$\mathrm{H} 3$} & 0.030 & 0.790 & 0.82 & 0.014 & 0.016 & - & - \\
\hline & & 3.65 & 96.34 & 100 & 1.70 & 1.95 & - & - \\
\hline & \multirow{2}{*}{$\mathrm{H} 4$} & 0.850 & - & 0.850 & 0.11 & 0.02 & - & 0.720 \\
\hline & & 100 & - & 100 & 12.9 & 2.35 & - & 84.7 \\
\hline
\end{tabular}

Table: 3 Day wise average of components of solid waste

\begin{tabular}{|l|l|l|l|l|l|l|}
\hline Days & Dry wt & Wet wt & Total wt & Paper & Plastic & Misc \\
\hline Day 1 & 0.179 & 0.543 & 0.73 & 0.0525 & 0.0266 & 0.103 \\
\hline Day 2 & 0.114 & 0.404 & 0.518 & 0.033 & 0.0266 & 0.0544 \\
\hline Day 3 & 0.204 & 0.371 & 0.55 & 0.04 & 0.044 & 0.119 \\
\hline Day 4 & 0.218 & 0.856 & 1.073 & 0.058 & 0.086 & 0.074 \\
\hline Day 5 & 0.535 & 0.412 & 0.948 & 0.033 & 0.166 & 0.335 \\
\hline Day 6 & 0.147 & 0.519 & 0.66 & 0.0254 & 0.032 & 0.089 \\
\hline Day 7 & 0.146 & 0.594 & 0.741 & 0.047 & 0.043 & 0.056 \\
\hline $\begin{array}{l}\text { Average } \\
(\%)\end{array}$ & 0.2204 & 0.527 & 0.7447 & 0.04127 & 0.0606 & 0.1172 \\
$(15.7 \%)$ \\
\hline
\end{tabular}

From Table-3 it can be understood that, $70.76 \%$ of the solid waste generated is wet waste (biodegradable) and the remaining $29.59 \%$ is dry waste (recyclable). The dry waste comprises of $5.5 \%$ paper, $8.13 \%$ plastic and $15.7 \%$ miscellaneous items including inert materials.

\subsection{Calculation for determining the density of total solid waste:}


The density of total solid waste mix is calculated by measuring average weights of waste sample without any compaction in a box of $200 \mathrm{ml}$ capacity for each of the five area segments during the sampling period of 7 days. The steps involved in the computation are given below for one set of data:

\section{Steps for calculating the density}

1. Empty weight of the box is $\mathrm{W} 1=25 \mathrm{~g}$

2. Weight of the box + weight of sample is $\mathrm{W} 2=77 \mathrm{~g}$

3. Weight of the sample is $\mathrm{W}=77-25=52 \mathrm{~g}=52 \times 10^{-3} \mathrm{~kg}$.

4. Volume of the sample is $200 \mathrm{ml}=200 \times 10^{-6} \mathrm{~m}^{3}$.

5. Density of the sample $=$ Weight of the sample/ Volume of the sample

$$
=52 \times 10^{-3} \mathrm{~kg} / 200 \times 10^{-6} \mathrm{~m}^{3}=260 \mathrm{~kg} / \mathrm{m}^{3}
$$

In the same manner, density for all the areas on all the 7 days of sampling are computed and given in Table-4. The average of the day-wise density is calculated and subsequently the average for the entire sampling period is calculated. The average density of the solid waste is Mylavaram is calculated as $302 \mathrm{~kg} / \mathrm{m}^{3}$.

Table-4: Density values of solid waste from Mylavaram

All values are in $\mathrm{kg} / \mathrm{m}^{3}$

\begin{tabular}{|l|l|l|l|l|l|l|l|}
\hline Days/area & Day 1 & Day 2 & Day 3 & Day 4 & Day 5 & Day 6 & Day 7 \\
\hline Area 1 & 225 & 235 & 160 & 325 & 275 & 216.5 & 229 \\
\hline Area 2 & 325 & 275 & 306 & 225 & 355 & 414.65 & 265 \\
\hline Area 3 & 375 & 385 & 430 & 275 & 225 & 313 & 290 \\
\hline Area 4 & 240 & 375 & 374.65 & 175 & 586.25 & 383.5 & 285 \\
\hline Area 5 & 475 & 325 & 209 & 275 & 235 & 225 & 300 \\
\hline Average & 328 & 319 & 295 & 255 & 335 & 310 & 275 \\
\hline
\end{tabular}

The density of total solid waste $=\sum$ average values $/ \mathrm{n}$

$$
\begin{aligned}
& =(328+319+295+255+335+310+275) / 7 \\
= & 302 \mathrm{~kg} / \mathrm{m}^{3}
\end{aligned}
$$

3.6 Calculation for determining the Moisture Content of total solid waste:

The component of solid waste is collected in a container and is dried in oven at $105 \mathrm{C}$ for 24 hours. The wet weight $\left(\mathrm{W}_{\mathrm{w}}\right)$ and dry weight $\left(\mathrm{W}_{\mathrm{d}}\right)$ are determined to calculate the moisture content using the formula [17]:

$$
\text { MoistureContent }(\%)=\frac{W_{w}-W_{d}}{W_{w}} \times 100
$$

The calculations are done for three days randomly out of 7 days of sampling and the steps involved in the computations are illustrated below.

\section{Steps for calculating the moisture content}

1. Empty weight of the box is W1 = 100 grams (gms)

2. Weight of the box + wet weight of sample is $\mathrm{W} 2=170 \mathrm{gms}$

3 . Wet Weight of the sample is $\mathrm{W}_{\mathrm{w}}=170-100=70 \mathrm{gms}$

4. Weight of the box + dry weight (oven dried) of sample is $\mathrm{W} 3=116.64 \mathrm{gms}$

5. Dry Weight of the sample is $\mathrm{W}_{\mathrm{d}}=116.64-100=16.64 \mathrm{gms}$

6. Moisture content of the sample $=\left(\mathrm{W}_{\mathrm{w}}-\mathrm{W}_{\mathrm{d}}\right) / \mathrm{W}_{\mathrm{w}} \times 100$

$$
=(70-16.64) / 70 \times 100=72.67 \%
$$

In the same manner, the calculations are done for each of three days for all the five sampling areas. The daily average and the overall average moisture content is determined. The details are given in Table-5. The average moisture content of the solid waste in Mylavarm is found to be $70 \%$ during the sampling period. However, for calculation purposes, the moisture content of food waste, paper, plastic, and inert material is considered as $70 \%, 6 \%, 5 \%, 8 \%$ respectively [17]. Ramakrishna [9] reported the density of solid waste in Rajam as $320 \mathrm{~kg} / \mathrm{m}^{3}$ and moisture content as $54 \%$. The density obtained for the solid waste in Mylavaram is close to that obtained in Rajam. However, the moisture content of the solid waste in Mylavaram is found to be high (71\%) compared to that obtained from Rajam. This may be attributed to the fact that Mylavaram is relatively a more rural area than that of Rajam, which is a Municipality and a very good business centre for the nearby villages. The energy content of the solid waste in Mylavaram is close to that obtained in Rajam (1900 kcal $/ \mathrm{kg})$ and slightly higher than that of Indian average values.

Table-5: Moisture content values of solid waste samples

\begin{tabular}{|l|l|l|l|}
\hline Areas/days & Day-1 & Day-2 & Day-3 \\
\hline Area-1 & 80 & 69 & 54.28 \\
\hline Area-2 & 62.17 & 67.98 & 80.96 \\
\hline Area-3 & 75.09 & 54.51 & 66.78 \\
\hline
\end{tabular}


All values are in \%

\begin{tabular}{|l|l|l|l|}
\hline Area-4 & 76.27 & 90 & 70.50 \\
\hline Area-5 & 82.71 & 55.36 & 63.50 \\
\hline Average & 75.524 & 67.37 & 66.948 \\
\hline
\end{tabular}

The Moisture content of solid waste $=\sum$ average values $/ \mathrm{n}$

$$
=209.84 / 3=70 \%
$$

The chemical composition, energy value, biogas generation are computed using the standard procedure [17] and are given in Table- 6 .

Table-6: Composition and characteristics of solid waste in Mylavaram

\begin{tabular}{|l|ll|l|}
\hline S No & Item particulars & Values \\
\hline 1 & Moisture content & $70 \%$ \\
\hline 2 & Average density, kg/m3 & 302 \\
\hline 3 & Component (average) & $\%$ by weight \\
& $-\quad$ Paper & \\
& $-\quad$ Plastic & 8.13 & \\
& $-\quad$ Food waste & 70.76 & \\
\hline 4 & Chemical Composition & $\mathrm{C}_{26.82} \mathrm{H}_{113.72} \mathrm{O}_{51.35} \mathrm{~N}$ \\
\hline 5 & Energy content & $2276 \mathrm{kcal} / \mathrm{kg}$ \\
\hline 6 & Air requirement for composting & $2579 \mathrm{~m}^{3} /$ tonne of waste \\
\hline 7 & Methane produced in landfill & $253 \mathrm{~m}^{3} /$ tonne of waste \\
\hline
\end{tabular}

\subsection{Quantification of solid waste in Mylavaram}

The samples are collected daily for one week and the quantity of solid waste samples are determined. The daily data is consolidated for each of the five routes and finally for the entire Mylavaram town. The results are as follows. Suitable assumptions are made wherever actual data measurement is not possible in computing the quantities.

Waste generation factors obtained:

- $\quad$ Residential waste $=0.748 \mathrm{Kg} /$ house

- Vegetable market $=6.96 \mathrm{~kg} / \mathrm{shop}$

- $\quad$ Hotels $=12.5 \mathrm{~kg} /$ hotel

- $\quad$ Restaurants $=7.5 \mathrm{~kg} / \mathrm{each}$

- Shops $=0.832 \mathrm{~kg} / \mathrm{shop}$

- Hospitals $=5 \mathrm{~kg} / \mathrm{each}$

- Fruit shops $=10 \mathrm{~kg} / \mathrm{shop}$

- $\quad$ Commercial establishments $=1.45 \mathrm{~kg} / \mathrm{shop}$

Computation for quantification of solid waste generation:

1. Total residential waste $=$ (number of houses $\mathrm{x}$ waste generated from house $)=4600 \times 0.748=3440 \mathrm{~kg} / \mathrm{day}$

2. Commercial waste $=$ (number of units $\mathrm{x}$ waste generated per unit)

- $\quad$ Vegetable markets $=50 \times 6.96=393 \mathrm{~kg} / \mathrm{d}$

- Hotels $=30 \times 12.5=375 \mathrm{~kg} / \mathrm{day}$

- $\quad$ Restaurants $=10 \times 7.5=75 \mathrm{~kg} / \mathrm{day}$

- Fruit Shops $=10 \times 10=100 \mathrm{~kg} / \mathrm{day}$

- Hospitals $=8 \times 5=40 \mathrm{~kg} / \mathrm{day}$

- $\quad$ Commercial units $=275 \times 1=275 \mathrm{~kg} /$ day

Total solid waste $=4698 \mathrm{~kg} /$ day

Add $25 \%$ for unaccounted $=1.25 \times 4698=\mathbf{6 0 0 0} \mathbf{~ k g} /$ day (rounded)

Per capita solid waste generation $=(6000 \mathrm{~kg} / \mathrm{d}) /(21763)=0.27 \mathrm{~kg} / \mathrm{cap} / \mathrm{day}$.

The per capita generation for population of $0.1-0.5$ million in India is $0.21 \mathrm{~kg} / \mathrm{cap} / \mathrm{day}$ [6]. The obtained value is close to that of the national average values. The above value is in close agreement with that reported by Ramakrishna [9] for the studies conducted for Rajam. Ramakrishna [9] reported a per capita solid waste generation of 0.214 for Rajam with a population of 42,000 . The population data of Mylavaram considered in the present study is as per the population census 2011. But, a large number of outside students studying in schools, colleges, educational institutes and commercial vendors who are commuting from nearby villages and other 
people are not accounted in the population data. The per capita solid waste generation may reduce slightly if the unaccounted population is taken into consideration.

\subsection{Route analysis}

The number of trips taken for each tractor (T) to carry solid waste is calculated. The volume of the three collection vehicles (tractors - T) is calculated based on storage dimensions. The values obtained are $\mathrm{T} 1$ $\left(2.52 \mathrm{~m}^{3}\right), \mathrm{T} 2\left(3.28 \mathrm{~m}^{3}\right)$, T3 $\left(1.70 \mathrm{~m}^{3}\right)$. Since, very little data is available in the field, the percentage of the distribution of houses in each area is assumed based on the knowledge of field survey and is given in Table- 7 . The steps for calculating the recommended trips by each tractor are given below:

1. The percentage of houses in area -1 is assumed as $30 \%$

2. The total waste generated in area $-1=$ step $-1 \times$ total solid waste $=30 / 100 \times 6000=1800 \mathrm{~kg}$

3. The volume of vehicle required to accommodate this solid waste $=$ weight/density $=1800 / 302=5.96 \mathrm{~m}^{3}$

4. The volume of tractor $\mathrm{T} 1$ is $2.52 \mathrm{~m}^{3}$, hence approximately two trips of $\mathrm{T} 1$ are sufficient to collect solid waste in area-1.

5. The volume obtained in the step 3 can be reduced further by compaction. Hence, a compaction factor value of 1.5 is assumed.

6. The recommended volume obtained after dividing step-3 with step-5 is $4 \mathrm{~m}^{3}(=5.96 / 1.5)$.

7. The volume of $\mathrm{T} 2$ is $3.28 \mathrm{~m}^{3}$. Hence, one trip of $\mathrm{T} 2$ is sufficient to collect this waste of $4 \mathrm{~m}^{3}$ volume. The recommended trips for the remaining areas are calculated similarly.

Table-7: Route Analysis for Mylavaram

\begin{tabular}{|l|l|l|l|l|l|l|}
\hline Area & \% of Area & Waste generation, $\mathbf{k g}$ & $\begin{array}{l}\text { Actual volume, } \\
\mathbf{m}^{3}\end{array}$ & $\begin{array}{l}\text { Actual trips } \\
\text { (vehicle } \\
\text { volume })\end{array}$ & $\begin{array}{l}\text { Compacted } \\
\text { volume, } \mathbf{m}^{3}\end{array}$ & $\begin{array}{l}\text { Recommended } \\
\text { trips }\end{array}$ \\
\hline $\mathrm{A} 1$ & 30 & $\begin{array}{l}1800 \\
(=0.3 \times 6000)\end{array}$ & 5.96 & $\begin{array}{l}\mathrm{T} 1 \times 2 \\
\left(=5.04 \mathrm{~m}^{3}\right)\end{array}$ & $\begin{array}{l}4 \\
(=5.96 / 1.5)\end{array}$ & $\begin{array}{l}\mathrm{T} 2 \times 1 \\
\left(\sim 3.28 \mathrm{~m}^{3}\right)\end{array}$ \\
\hline $\mathrm{A} 2$ & 30 & $\begin{array}{l}1800 \\
(=0.3 \times 6000)\end{array}$ & 5.96 & $\begin{array}{l}\mathrm{T} 2 \times 2 \\
\left(=6.56 \mathrm{~m}^{3}\right)\end{array}$ & $\begin{array}{l}4 \\
(=5.96 / 1.5)\end{array}$ & $\begin{array}{l}\mathrm{T} 1 \times 2 \\
\left(5.04 \mathrm{~m}^{3}\right)\end{array}$ \\
\hline $\mathrm{A} 3$ & 10 & $\begin{array}{l}600 \\
(=0.1 \times 6000)\end{array}$ & 1.98 & $\begin{array}{l}\mathrm{T} 3 \times 1 \\
(=1.7)\end{array}$ & $\begin{array}{l}1.3 \\
(=1.98 / 1.5)\end{array}$ & \\
\hline $\mathrm{A} 4$ & 15 & $\begin{array}{l}900 \\
(=0.15 \times 6000)\end{array}$ & 2.98 & $\begin{array}{l}\mathrm{T} 3 \times 2 \\
\left(=3.4 \mathrm{~m}^{3}\right)\end{array}$ & $\begin{array}{l}2 \\
(=2.98 / 1.5)\end{array}$ & $\begin{array}{l}\mathrm{T} 3 \times 1 \\
\left(1.7 \mathrm{~m}^{3}\right)\end{array}$ \\
\hline A5 & 15 & $\begin{array}{l}900 \\
(=0.15 \times 6000)\end{array}$ & 2.98 & $\begin{array}{l}\mathrm{T} 1 \times 1 \\
\left(2.52 \mathrm{~m}^{3}\right)\end{array}$ & $\begin{array}{l}2 \\
(=2.98 / 1.5)\end{array}$ & $\begin{array}{l}\mathrm{T} 3 \times 1 \\
\left(=1.7 \mathrm{~m}^{3}\right)\end{array}$ \\
\hline
\end{tabular}

It can be noted from Table-7 that, the actual number of trips for collecting the solid waste from Mylavaram are 8 $(=2+2+1+2+1)$. If compaction of 1.5 is adopted, then the number of trips will be reduced to $5(=1+2+1+1)$. This will save man hours, engaging vehicles and subsequently revenue currently being incurred.

\subsection{Recovery of total solid waste generated per day}

The recovery values of the plastic, paper and compost are noted down based on personal interactions with vendors at Mylavaram. The necessary calculations are done as per the procedure outlined by Ramakrishna [9]. The details are given below:

\subsubsection{Recovery value of compost and methane from landfill}

Total solid waste generated per day $=6000 \mathrm{~kg} / \mathrm{day}$

Biodegradable waste $=4260 \mathrm{~kg} / \mathrm{day}$ (@ 71\%)

This can be used for composting as well as in landfill. Assuming 3.26 tonnes of solid waste is used for composting and remaining 1 tonnes for landfilling, the calculations that can be made are as follows.

\section{Compost:}

Recovery value of compost: $25-50 \%[18,19]$.

Assuming 35\% recovery, compost recovered $=3.26 \times 0.35=1.141$ Tonnes per day.

Recovery value @ Rs 3000 per tonne [10]=1.141 x $6000=$ Rs 3423

However, the recovery value is reported as high as Rs 6000 per tonne [20].

\section{Biogas from Landfill:}

Biogas generation $=1 \times 253=253 \mathrm{~m} 3$ per day

Assuming cost of $1 \mathrm{~m}^{3}$ of biogas [21] = Rs 8.50 
Recovery value $=253 \times 8.5=$ Rs 2150.5 per day.

The detailed breakup of recovery values for different combinations of solid waste used for composting and landfilling are computed to study the best combination that can be used and is given in Table-8.

Table-8: Recovery value options for different combinations of biodegradable solid waste for composting and landfilling

\begin{tabular}{|l|l|l|l|l|l|l|}
\hline $\begin{array}{l}\text { S } \\
\text { No }\end{array}$ & $\begin{array}{l}\text { Solid Waste for } \\
\text { composting, Tonnes }\end{array}$ & $\begin{array}{l}\text { Recovery value, } \\
\text { Rs }\end{array}$ & $\begin{array}{l}\text { Solid waste for } \\
\text { landfill, Tonnes }\end{array}$ & $\begin{array}{l}\text { Biogas } \\
\text { generated, } \mathbf{~ m}^{\mathbf{3}}\end{array}$ & $\begin{array}{l}\text { Recovery } \\
\text { value, Rs }\end{array}$ & $\begin{array}{l}\text { Total recovery } \\
\text { value, Rs }\end{array}$ \\
\hline 1 & 4.26 & 4473 & 0 & 0 & 0 & 4473 \\
\hline 2 & 3.26 & 3423 & 1 & 253 & 2151 & 5574 \\
\hline 3 & 2.26 & 2373 & 2 & 506 & 4301 & 6674 \\
\hline 4 & 1.26 & 1323 & 3 & 759 & 6452 & 7775 \\
\hline 5 & 0.26 & 273 & 4 & 8602 & 8875 \\
\hline
\end{tabular}

The effective solid waste management would be realised if major portion of solid waste is recovered in some form or other while only minor portion would be disposed in a landfill. More quantity of solid waste for landfill disposal would result in more land area and other operational and pollution problems. Recovery of major portion of solid waste would bring revenue in addition to its disposal. Hence, an optimum combination for choosing the right combination of quantities for compost and biogas generation is attempted and is shown in Fig. 4. It is noted from Fig.4 that, the optimum quantities would result in a revenue of Rs 3000 from compost and Rs 3000 from biogas recovery making a total recovery of Rs 6000.

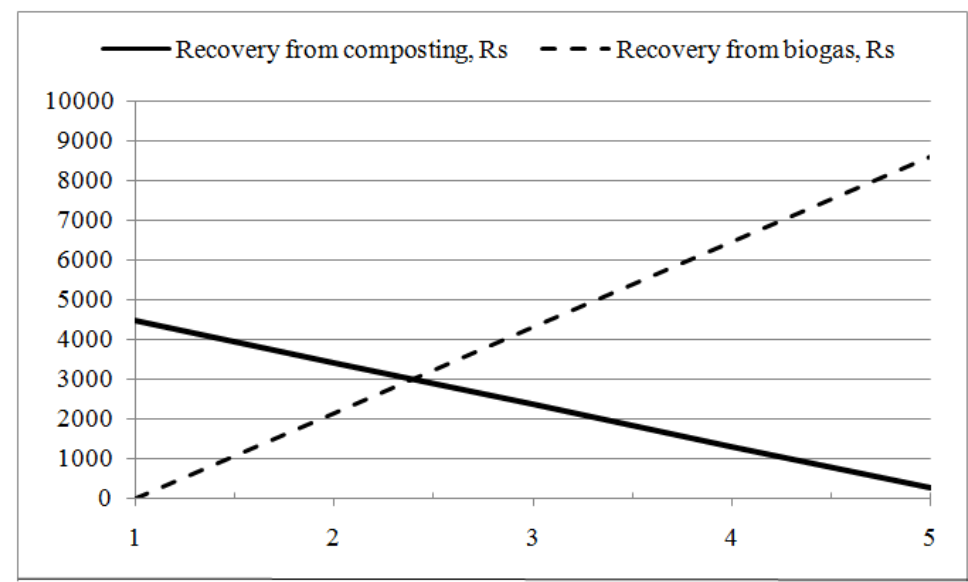

Fig. 4: Recovery value comparison between composting and landfilling

However, this is Rs. 2875 less than the best combination (\#5). The option-5 shows 4 tonnes of solid waste for landfilling and the remaining 0.26 tonnes for composting. This is not a right choice since this requires more land area for landfilling with minimum revenue from composting. Though monetarily, it is a better option, this is not advisable from environmental management point of view. Hence a combination of 2.86 tonnes for composting and 1.4 tonne for landfilling with a net recovery of Rs 6000 per day may be adopted. Based on this observation, the optimum quantities of solid waste that can be used for compost generation and for biogas recovery are calculated as follows:

Solid waste required for composting $=(3000 /(3000 \times 0.35))=2.86$ tonnes $/$ day

Solid waste required for biogas recovery $=(3000 /(8.5 \times 253))=1.4$ tonnes $/$ day

\subsubsection{Calculation of land required for landfilling of biodegradable waste}

Bio-degradable waste generated per day $=1.4$ tonne $=1400 \mathrm{~kg}$ (as obtained above)

Bio-degradable waste for ten years of filling $=1400 \times 365 \times 10=5110000 \mathrm{~kg}$

Volume required for landfilling for ten years $=$ total solid waste $/$ density of solid waste

$$
=5110000 / 302=16920.5 \mathrm{~m}^{3}
$$

Assuming depth of effective filling as $3 \mathrm{~m}$.

Area required for landfilling $=$ Volume $/$ depth

$$
=16920.5 / 3=5641 \mathrm{~m}^{2}
$$

Assuming $100 \%$ allowance for making roads, fencing, infrastructure and other facilities,

Area required $=2 \times 5641=11282 \mathrm{~m}^{2}=\mathbf{1 . 1 2 8}$ Hectare 


\subsubsection{Recovery value for paper and plastic}

Non-biodegradable solid waste $=6000 \times 0.29=1740 \mathrm{~kg} / \mathrm{day}$

\section{Recovery for paper:}

Amount of paper: $8.42 \times 1740 / 100=146.508 \mathrm{~kg} /$ day

Assuming $50 \%$ is not recoverable $=73.254 \mathrm{~kg} /$ day.

Recovery value @ Rs 10 per kg of paper [16]=73.254 x 10=Rs 732.54 per day

Recovery for Plastic:

Amount of plastic $=6.28 \times 1740 / 100=109.272 \mathrm{~kg} / \mathrm{day}$

Assuming $50 \%$ is not recoverable $=54.636 \mathrm{~kg} / \mathrm{day}$

Recovery value @ Rs 15 per kg of plastic [16]=109.272 x 15= Rs 819.54 per day

\subsubsection{Total recovery value from solid waste}

The total recovery value from solid waste $=$ Recovery value from bio degradable waste + Recovery value from non-bio degradable waste.

The total recovery value from solid waste $=6000+732.54+819.54$

$$
=\text { Rs 7,552 per day or Rs } 27.5 \text { lakhs per year. }
$$

However, it should be noted that construction and operation costs for composting and landfilling are not included. Since it is an investment, it can be recovered quickly in a few years from the operation. It should be noted that, the recovery value is maximum ( $85.27 \%$ ) from biodegradable waste and hence waste recovery practices should be followed. Moreover, recovery value of paper and plastics $(14.73 \%)$ is possible only when segregation of these components is made at the source of generation. Contamination of these components may lead to higher side of non-recoverable portion and the recovery value will be reduced further.

\subsubsection{Disposal of residual solid waste in dumpsite}

The sanitary landfill area that is obtained above from disposal of biodegradable fraction of solid waste is 1 hectare, where biogas recovery is possible. However, some portion of waste residues and fraction of nonrecoverable non-bio-degradable solid waste should also be disposed off. This can be safely disposed in a dump site. The calculations made for this purpose are as follows:

1. Residue from compost making @ 35\% recovery rate $=0.65 \times 2.86=1,860 \mathrm{~kg} / \mathrm{day}$

2. Non-recoverable fraction from non-biodegradable waste $=1740-(73.25+54.63)=1612 \mathrm{~kg} / \mathrm{day}$

3. Total residue from solid waste generated $=1860+1612=3472 \mathrm{~kg} / \mathrm{day}$

4. For 10 years of collection and disposal $=3472 \times 365 \times 10=126,72,800 \mathrm{~kg}$

5. Volume of this waste $=126,72,800 / 302=41,963 \mathrm{~m}^{3}$

6. Area required @ $3 \mathrm{~m}$ depth of filling $=41,963 / 3=13,988 \mathrm{~m}^{2}=1.4$ hectares

7. Add $100 \%$ allowance for creating internal roads, greenery, compound wall and other infrastructural facilities. Total area required $=1.4 \times 2=2.8$ hectares

Hence the total area required for landfilling the solid waste from Mylavaram is 1.128 hectare for sanitary landfilling and 2.8 hectare for dumping the residual solid waste. In case the biogas is not recovered, a total of $3.93(=1.128+2.8)$ hectares or approximately 4 hectares is required for dumping the entire solid waste generated from Mylavaram. The recovery value from the solid waste will be restricted to Rs 4552 per day or Rs 16.61 lakhs per year.

\section{Summary And Conclusions}

Solid waste management practices at Mylavaram, Krishna District, Andhra Pradesh is studied. Currently no systematic practices are being followed. House-to-house collection of solid waste is irregular while collected solid waste is dumped at two locations outside Mylavaram. Systematic studies are made and computations are done for determination of composition, characterization, quantification, route analysis and recovery value of the solid waste. Few suggestions are floated in this regard with respect to dumping of waste in a dump site, recovery from composting and biogas generated from landfill. Land area requirements with and without sanitary landfill options are floated. A total recovery of Rs 27.5 lakhs or Rs 16.61 lakhs is possible with and without recovery of biogas respectively. In case the biogas is not recovered, a total of 4 hectares is required for dumping the entire solid waste generated from Mylavaram.

\section{Acknowledgements}

The authors wishes to acknowledge the help and cooperation provided by The Sanitary Inspector, Gram Panchayat, Mylavaram for providing the necessary data and help during field studies from time to time.

\section{References}


[1] CPCB, Status Report on Municipal Solid Waste Management. available on internet at http:// www. cpcb. nic.in/ divisionsofheadoffice/pcp/MSW_Report.pdf.

[2] Firdaus G. and A. Ahmad, Management of Urban Solid Waste Pollution in Developing Countries, International Journal of Environment Research, 4(4):795-806, Autumn 2010.

[3] Sridharan V, R Jayant, V Rajagopal, N Srinivasan, G Agarwal and V Ramakrishna, Impact of Socio-Economic Status of a Community on Municipal Solid Waste Characteristics - A Case Study, Proceedings of National Conference on Environmental Conservation (NCEC-2006), September 1-3, Birla Institute of Technology and Science-Pilani,2006, 795-802.

[4] CPCB, Status of Municipal Solid waste Generation, Collection, Treatment and Disposal in Class I Cities, Series: ADSORBS/31/1999-2000

[5] Singhal S and S. Pandey, Solid waste management in India: status and future directions, TERI Information Monitor on Environmental Science, 6 (1), 2001, 1-4.

[6] Sharholy Mufeed, Kafeel Ahmad, Gauhar Mahmood, and R.C. Trivedi, Municipal solid waste management in Indian cities - A review, Waste Management 28 (2008) 459-467.

[7] Asnani P.U., Solid Waste Management, Available on internet at http:/ /www.iitk.ac.in/ 3inetwork/html/ reports/IIR2006/Solid_ Waste.pdf, 2006

[8] CPCB, Status of solid waste generation, collection, treatment and disposal in metro cities. Central Pollution Control Board, Delhi, 1999.

[9] Ramakrishna V. Municipal Solid Waste Quantification, Characterization and Management in Rajam, The International Journal of Engineering and Science (IJES) ISSN (e): 2319 - 1813 ISSN (p): 2319 - 1805, 5 (2), 2016, 40-47.

[10] Handa K., Anamika Paul and Preeti Jain, Status of composting in India with emphasis on Delhi, International Journal for Research and Applied Sciences, I(IV), Nov 2013, pp. 60-64. ISSN 2321-9653.

[11] Ashwani Kumar, Existing Situation of Municipal Solid Waste Management in NCT of Delhi, India. Research Forum: International Journal of Social Sciences; ISSN: 2348 4411, 2013, 1 (1).

[12] Swapandas and B. K. Bhattacharya, Municipal Solid Waste Characteristics and Management in Kolkata, India. International Journal of Emerging technology and advanced engineering; ISSN: 2250-2459 ISO 9001: 2008, 3 (2), Feb 2013.

[13] Joshi M.P., S.B.Patil, and K. Mourya, Solid Waste Management on dumping ground in Mumbai Region: A case study, International Journal of Computer Applications (0975 - 8887), International conference on Green Computing and Technology (ICGCT/Number 3 (ISBN: 973-93-80877-93-2)),2013, pp. 18-22.

[14] MCGM. Municipal Corporation of Greater Mumbai, Available via internet at http://www. mcgm.gov.in/irj/ portal/ anonymous/ qlcleanover\#key

[15] VMC. Solid Waste Management in Vijayawada, Available via internet at https://www.ourvmc.org/jnnurm/ch45.pdf., 2016

[16] Personal Communication. Personal Communication with Sanitary Inspector, Gram Panchayat office, Mylavaram, 2016.

[17] Peavy H.S., D. Rowe, G. Tchobanoglous., Environmental Engineering (McGraw Hill Publications, Singapore, 1985).

[18] Adamu Isa Harir, Rozilah Kasim, and Bala Ishiyaku, Exploring the Resource Recovery Potentials of Municipal Solid Waste: A review of solid wastes composting in Developing Countries. International Journal of Scientific and Research Publications, 5(4), April 2015.

[19] Richard T.L.. Municipal Solid Waste Composting: Physical Processing. Available on internet at http://compost.css .cornell.edu/ MSWFactSheets/msw.fsl.html, 2016.

[20] Agriculture Information, News letter available on internet at http://www.agricultureinformation.com/forums/sale/52727vermicompost-sale.html.

[21] IIT Delhi. Entrepreneurship models on biogas for Rural areas. available on internet at http:/ /web. iitd.ac.in/ vkvijay/ Entrepreneurship\%20Models\%20on\%20Biogas\%20for\%20Rural\%20Areas.pdf, 2016. 